of the Institute of Fuel during 1949-51 and in 1950 was awarded its highest honour, the Melchett Medal, choosing "Ignipotence" as the subject of his address. In this address he described some of the researches in his department, where incidentally there is now a record number of postgraduate students; the researches include work on coal chemistry, the reactivity, properties and production of metallurgical coke, heat transfer, furnace design, smoke repression. in metallurgical operations, and gasification of lowgrade fuels.

Mr. M. W. Thring

Mr. M. W. Thring, who succeeds Prof. Sarjant, was educated at Malvern College and Trinity College, Cambridge, graduating with first-class honours in Part 1 of the Mathematical Tripos and in Part 2 of the Natural Sciences Tripos. In 1937 he joined the staff of the newly formed British Coal Utilization Research Association, becoming head of the Com bustion Research Laboratory in 1944. Experimental and theoretical work on the velocities and temperature drop in producer gas mains led to the award of the Student Medal of the Institute of Fuel in 1938 Among his war-time studies were the design of portable gas producers and the development of the down-jet system of combustion in fuel beds; these investigations culminated in a major study of port designs in open-hearth furnaces, carried out in 1944 in collaboration with Dr. J. H. Chesters, of the United Steel Companies, Ltd., and in $1949 \mathrm{Mr}$. Thring was awarded the Sir Robert Hadfield Medal of the Iron and Steel Institute for studies on open-hearth furnaces. In 1946 he took up a new post as head of the Physics Department of the British Iron and Steel Research Association, later being appointed superintendent and, recently, assistant director of the Association. In 1949 he took part in the early discussions leading to the formation of the International Committee for Research on Luminous Flame Radia tion, and two years later became general superintendent of its researches. Mr. Thring is the author of a book on "The Science of Flames and Furnaces" and of many papers on fuel subjects, and he has made valuable contributions to the theoretical understanding of radiation during combustion and of the mechanism of combustion in turbulent jet flames.

\section{Atomic Energy Research in Britain}

REPLYING to a question in the House of Commons on April 28, Sir Winston Churchill stated that the Government has set up a committee, consisting of Lord Waverley (chairman), Sir Wallace Akers and Sir John Woods, with the following terms of reference : "To devise a plan for transferring responsibility for atomic energy from the Ministry of Supply to a nondepartmental organization and to work out the most suitable form for the new organization, due regard being paid to any constitutional and financial implications". He remarked that considerable strides have been made in the development of methods of using atomic energy for industrial purposes, and these aspects are now coming very much to the fore. A non-departmental organization is considered by the Government to be necessary to secure rapid and economical development, for both military and industrial purposes, and the committee has the task of visiting the various establishments concerned with the view of devising a form of organization to meet the very special needs of the case. Overall policy must remain firmly in the hands of the
Government, and methods of financial control will have to be devised since in the foreseeable future the considerable cost will fall on public funds. The rights and interests of existing staff in atomic energy establishments will be fully respected. It will be recalled that in July 1951, Lord Cherwell, speaking in the House of Lords, asked for the transfer of atomic energy development to some such nondepartmental agency.

\section{Atomic Energy Establishments in Britain}

ON May 4, Mr. Duncan Sandys, Minister of Supply, gave some information in the House of Commons about the work of atomic energy establishments in Great Britain. $\mathrm{He}$ said that Harwell is responsible for fundamental research into nuclear physics and atomic energy, and provides basic scientific information to the other establishments. The radio-chemical centre at Amersham is an offshoot of Harwell. It deals with the preparation of radioactive substances such as radium, radon, and radioactive isotopes produced in the atomic piles, and these are used for medical, scientific and industrial purposes. The production of fissile material is directed from headquarters at Risley, near Warrington, where the design and planning offices are situated. A factory at Springfields, near Preston, produces pure uranium from uranium concentrates ; another, at Windscale, in Cumberland, produces plutonium from uranium by means of atomic piles ; and a third, at Capenhurst, in Cheshire, has a gaseous diffusion plant for separating uranium-235 from the more abundant isotope uranium-238, producing a fissile material which can be used as an alternative to plutonium. Research work on atomic weapons is carried on at Aldermaston, in Berkshire, and its out-stations at Woolwich and Fort Halstead.

\section{Effects of Toxic Substances on Wild Life}

A WRITten reply by the Minister of Agriculture, Sir Thomas Dugdale, given in the House of Commons on May 4, stated that the working party considering precautionary measures in the agricultural use of toxic substances has been reconstituted under the chairmanship of Prof. S. Zuckerman and will now consider the effects of such substances on wild life in general. It will include representatives of the agricultural departments, the Agricultural Research Council, the Agricultural Improvement Council, the Nature Conservancy, the fisheries departments, and the Medical Research Council. Its terms of reference will be: "To investigate the possible risks to the natural flora and fauna of the countryside from the use in agriculture of toxic substances, including the possible harmful effects for agriculture and fisheries, and to make recommendations".

\section{Exhibition in the Science Museum, London, of Historic Books on Machines}

THE second of a series of special exhibitions of historic books relative to science and technology was opened at the Science Museum, London, on May 1 and will remain on view to the public, free of charge, until August 30 (weekdays, 10 a.m. -6 p.m.; Sundays, $2.30-6$ p.m.). The exhibition deals with machinery and traces the development of machines from classical times up to the period of the Industrial Revolution in the eighteenth century. Although some of the very early machines were exceedingly crude in appearance, they often embodied fundamental principles which were taken up in later times 